九州大学学術情報リポジトリ

Kyushu University Institutional Repository

\title{
ANTS COLLECTED IN PINE FORESTS INFESTED BY THE PINE NEEDLE GALL MIDGE IN KOREA (HYMENOPTERA, FORMICIDAE)
}

Ogata, Kazuo

Hirashima, Yoshihiro

Miura, Tadashi

Maeta, Yasuo

他

https://doi.org/10.5109/2483

出版情報: ESAKIA. 23，pp.159-163，1985-11-30. Entomological Laboratory，Faculty of Agriculture, Kyushu University バージョン :

権利関係 : 


\title{
ANTS COLLECTED IN PINE FORESTS INFESTED BY THE PINE NEEDLE GALL MIDGE IN KOREA (HYMENOPTERA, FORMICIDAE) ${ }^{12(3)}$
}

\author{
Kazuo Ogata, Yoshihiro Hirashima \\ Entomological Laboratory, Faculty of Agriculture, \\ Kyushu University, Fukuoka 812, Japan \\ Tadashi Miura, Yasuo Maeta \\ Laboratory of Insect Management, Faculty of Agriculture, \\ Shimane University, Matsue 690, Japan

\section{KoJI Yano} \\ Entomological Laboratory, Faculty of Agriculture, \\ Y amaguchi University, Yamaguchi 753, Japan \\ and \\ JE-HO Ko \\ Department of Forest Entomology and Pathology, \\ Forest Research Institute, Seoul 131, Korea
}

\begin{abstract}
Twenty-two species of ants are collected from red and black pine forests infested by the pine needle gall midge, Thecodiplosis japonensis, in Korea. Some of these ants are expected to be predators of the latter.
\end{abstract}

During the years 1983-1984, the Japan-Korea cooperative survey was made on the natural enemies of the pine needle gall midge, Thecodiplosis japonensis, in Korea. This paper reports on the ant fauna of the Korean pine forests as a result of the survey.

A total of 22 ant species was determined from the present collection, some of

1) Supported by a grant (1983-84) from the Japan Society for the Promotion of Science, Tokyo (Principal investigators: T. Miura and J. H. Ko).

2) Contribution from the Department of Forest Entomology and Pathology, Forest Research Institute, Seoul, Korea.

3) Contribution from the Entomological Laboratory, Faculty of Agriculture, Kyushu University, Fukuoka (Ser. 3, No. 196). 
which are expected to be predators of the pine needle gall midge. All the material was collected on trees and ground in the midge-infested pine forests.

\section{List of collecting sites}

1. Gang Weon Do

Hongch'bn, Hongch’ơn-gun, June 29, 30, 1983 (Y. Hirashima) ; June 19, 20, 1984 (K.

Yano) ; September 1, 4, 1984 (Y. Maeta).

2. Seoul

Forest Experiment Station. July 4, 1983 (Y. Hirashima).

3. Ch'ungch'ŏng Nam Do

Kwangchang-ri, Poryong-gun, November 3, 1984 (K. Yano).

Namgok-ri, Poryong-gun, June 14, 1984 (K. Yano).

Sajom-ri, Cheongnyong-gun, June 14, 1984 (K. Yano).

Bibong, Cheongnyong-gun, September 6, 1984 (Y. Maeta).

Whasong, Cheongnyong-gun, September 6, 1984 (Y. Maeta).

Shindai-ri, Yesan-gun, June 14, 1984 (K. Yano).

Kwangshi, Yesan-gun, September 6, 1984 (Y. Maeta).

Daichon, September 6, 1984 (Y. Maeta).

\section{List of the species}

Subfam. Ponerinae

1. Ectomomyrmex javanus Mayr(ツシマハリ7リ)

Hongch'on, 30. vi. 1983, 1 worker (Y. Hirashima) ; Whasong, 6. ix. 1984, 1 winged female (Y. Maeta).

This is the largest ponerine ant in Korea. Synonymic list of the species was given by Yasumatsu (1962). There are still some confusion about the taxonomic status of the the species. Collingwood (1976) treated the name E. javanus as the junior synonym of Pachycondyla astuta (F. Smith), without any discussion about the relationship between the genera Ectomomyrmex and Pachycondyla. Paik (1984) listed E. astutas in his check list of Korean ants. These changes are concerned not only with the species level but also with the generic level, because $E$. javanus is the type-species of the genus. Brown (1973) suggested that most of the genera of the tribe Ponerini may be synonymous with the genus Pachycondyla, but any formal taxonomic changes have not been made. In any case, to avoid unnecessary confusion, it should be better to reserve the name " $E$. javanus", until the whole tribe is completely revised.

Subfam. Myrmicinae

2. Myrmica rugiondis Nylander (シ 73 シケアリ)

Hongch’ŏn, 20. vi. 1984, 1 worker (K. Yano), 4. ix. 1984, 6 workers (Y. Maeta). 
The species is one of the most common Myrmica ant in the Palaearctic Region, ranging from Europe to Japan. Collingwood (1976) recorded M. yoshiokai Weber from North Korea, but Elmes and Clarke (1981) thought that it is synoymous with $M$. muginodis. At least, the samples collected this time from Korea agree with Japanese ruginodis.

\section{Myrmica sp. 1 (nr. sulcinodis Nylander)}

Hongch'ǒn, 29. vi. 1983, 2 workers (Y. Hirashima), 20. vi. 1984, 2 workers (K. Yano), 1. ix. 1984, 1 worker (Y. Maeta), 4. ix. 1984, 4 workers (Y. Maeta).

The species is characteristic in having sharply curved antennal scape at its base where lamellate outgrowth is weakly developed, and strongly ridged lateral portion of clypeus in front of antennal insertion.

\section{Myrmica sp. 2 (nr. schenki Emery)}

Hongch'ǒn, 30. vi. 1983, 9 workers (Y. Hirashima).

The species is similar to schenki Emery from Europe in having small but distinct tooth-like projection at the bent of antennal scape, and sharrow metanotal groove. But it differs by the shape of antennal carinae which are not so widely diverging as in schenki, and by the dorsal profile of petiolar node which is not truncate.

5. Pheidole fervida F. Smith (アズマオオズアカアリ)

Seoul, 4. vii. 1983, 43 workers, 14 soldiers (Y. Hirashima) ; Kwangshi, 6. ix. 1984, 1 worker (Y. Maeta).

6. Tetramorium caespitum (Linnaeus) (トビイロシ 7 アリ)

Hongch'bn, 29. vi. 1983, 3 workers, 1 male, (Y. Hirashima) ; Seoul, 4. vii. 1983, 8 workers (Y. Hirashima) ; Kwangshi, 6. ix. 1984, 6 workers (Y. Maeta); Daichon, 6. ix. 1984, 2 workers (Y. Maeta).

\section{Leptothorax sp. (nr. spinosior Forel)}

Hongch'on, 29. vi. 1983, 1 worker (Y. Hirashima).

The species is characteristic in having 12-segmented antenna of which the scape is reaching to posterior corner of head, weakly rounded dorsum of trunk without distinct metanotal groove, and long and acute propodeal spine which is gently curved downward.

\section{Pristomyrmex pungens $\operatorname{Mayr}$ (アミメアリ)}

Hongch’ðn, 29. vi. 1983, 20 workers (Y. Hirashima), 19. vi. 1984, 27 workers (K. Yano), 4. ix. 1984, 7 workers (Y. Maeta); Seoul, 4. vii. 1983, 4 workers (Y. Hirashima) ; Bibong, 6. ix. 1984, 1 worker (Y.Maeta); Whasong, 6. ix. 1984, 4 workers (Y. Maeta); Shindai-ri, 14. vi. 1984, 1 worker (K. Yano) ; Kwangshi, 6. ix. 1984, 8 workers (Y. Maeta); Daichon, 6. ix. 1984, 45 workers (Y. Maeta). 
9. Crematogaster sordidula osakensis Fore1 (キイロシリアゲ 7 リ)

Seoul, 4. vii. 1983, 1 worker (Y. Hirashima) ; Bibong, 6. ix. 1984, 4 workers (Y. Maeta); Kwangshi, 6. ix. 1984, 3 workers (Y. Maeta).

10. Crematogaster matsumurai Forel(ハリブトシリ 7 ゲ 7 リ)

Hongch'ðn, 19. vi. 1984, 3 workers (K. Yano), 20. vi. 1984, 1 worker (K. Yano), 4. ix. 1984, 16 workers (Y.Maeta); Seoul, 4. vii. 1983, 4 workers (Y. Hirashima) ; Whasong, 6. ix. 1984, 11 workers (Y. Maeta); Kwangshi, 6. ix. 1984, 1 worker (Y. Maeta).

11. Crematogas ter vagula Wheeler

Daichon, 6. ix. 1984, 1 worker (Y. Maeta).

This is the first record of this species from Korea. This species is characteristic in having dorsally sculptured but laterally smooth pronotum, short but acute propodeal spine, and small ventral tooth of the petiole.

Subfam. Formicinae

12. Paratrechina flavipes (F. Smith) (7メIロロ7リ)

Hongch'ǒn, 29. vi. 1983, 63 workers (Y. Hirashima), 19. vi. 1984, 45 workers (K. Yano), 20. vi. 1984, 63 workers (K. Yano), 1. ix. 1984, 26 workers (Y. Maeta), 4. ix. 1984, 53 workers (Y. Maeta); Seoul, 4. vii. 1983, 18 workers (Y. Hirashima) ; Bibong, 6. ix. 1984, 1 worker (Y. Maeta); Whasong, 6. ix. 1984, 5 workers (Y. Maeta); Shindai-ri, 14. vi, 1984, 6 workers (K. Yano) ; Kwangshi, 6. ix. 1984, 46 workers (Y. Maeta); Daichon, 6. ix. 1984, 10 workers (Y. Maeta)

13. Paratrechina sakurae (Ito) (サクラ 7 リ)

Seoul, 4. vii. 1983, 1 worker (Y. Hirashima).

14. Lasius niger (Linnaeus)（トビイロケ7リ)

Hongch'ǒn, 19. vi. 1984, 71 workers (K. Yano), 20. vi. 1984, 16 workers (K. Yano) ; Seoul, 4. vii. 1983, 85 workers (Y. Hirashima).

15. Lasius sp. (nr. niger)

Hongch'ŏn, 19. vi. 1984, 1 worker (K. Yano), 20. vi. 1984, 4 workers (K. Yano).

Probably these are materials from unmatured colonies of L. niger.

16. Plagiolepis manczshurica Ruzsky

Shindai-ri, 14. vi. 1984, 5 workers (K. Yano) ; Kwangshi, 6. ix. 1984, 4 workers (Y. Maeta); Daichon, 6. ix. 1984, 2 workers (Y. Maeta).

17. Plagiolepis flavescens Collingwood Hongch'bn, 20. vi. 1984, 8 workers (K. Yano), 1. ix. 1984, 3 workers (Y. Maeta). 
18. Formica japonica Motschulsky (クロヤマアリ)

Hongch’ðn, 29. vi. 1983. 6 workers, 1 male (Y. Hirashima), 30. vi. 1983, 7 workers (Y. Hirashima), 19. vi. 1984, 2 workers (K. Yano) ; Seoul, 4. vii. 1983, 9 workers (Y. Hirashima) ; Namgok-ri, 14. vi. 1984, 6 workers (K. Yano) ; Sajom-ri, 14. vi. 1984, 2 workers (K. Yano) ; Whasong, 6. ix. 1984, 1 worker (Y. Maeta); Shindai-ri, 14. vi. 1984, 5 workers (K. Yano) ; Daichon, 6. ix. 1984, 4 workers (Y. Maeta).

19. Formica yessensis Fore1 (エゾアカヤマアリ)

Hongch’ǒn, 30. vi. 1983, 19 workers (Y. Hirashima).

20. Camponotus japonicus Mayr (3 ロオオアリ)

Hongch’ǒn, 29. vi. 1983, 18 workers (Y. Hirashima), 30. vi. 1983, 25 workers (Y. Hirashima) ; Seoul, 4. vii. 1983, 9 workers (Y. Hirashima) ; Kwangchang-ri, 3. xi. 1984, 6 workers (K. Yano) ; Namgok-ri, 14. vi. 1984, 9 workers (K. Yano) ; Bibong, 6. ix. 1984, 6 workers (Y. Maeta); Whasong, 6. ix. 1984, 1 worker, (Y.Maeta); Shindai-ri, 14. vi. 1984, 1 worker (K. Yano) ; Kwangshi, 6. ix. 1984, 3 workers (Y. Maeta); Daichon, 6. ix. 1984, 3 workers (Y. Maeta).

21. Camponotus sp. (nr. nipponensis Santschi)

Hongch'bn, 20. vi. 1984, 1 worker (K. Yano).

The species is similar to C. nipponensis Santschi from Japan, in having many standing hairs (more than 40) on the dorsum of the trunk.

22. Polyrhachis lamellidens F. Smith(トゲアリ)

Kwangchang-ri, 3. xi. 1984, 2 winged females (K. Yano).

\section{References}

Brown, W. L., Jr., 1973. A comparison of the Hylean and Congo-West African rain forest and faunas. In 'Tropical forest ecosystems in Africa and South America, a review" ed. by Meggers, B. J., E. S. Ayensu and W. D. Duckworth. pp. 161-185, Washington, E. C.

Collingwood, C. A., 1976. Ants (Hymenoptera, Formicidae) from North Korea. Ann. Hist.-nat. Mus.Nat. Hung., 68 : 295-309.

- , 1981. Ants (Hymenoptera, Formicidae) from North Korea, 2. Folia Ent. Hung., 42 : 25-30.

Elmes, G. W. and R. T. Clarke, 1981. A biometric investigation of variation of workers of Mymica ruginodis Nylander (Formicidae). In : Systematic association special vol. 19, "Biosystematics of Social Insects" ed. by P. E. House and J.-L. Clement. pp. 121-140, Academic Press, London.

Paik, W. H., 1984. A check list of Formicidae (Hymenoptera) of Korea. Korean J. Plant Prot., 23 : 193-195. 


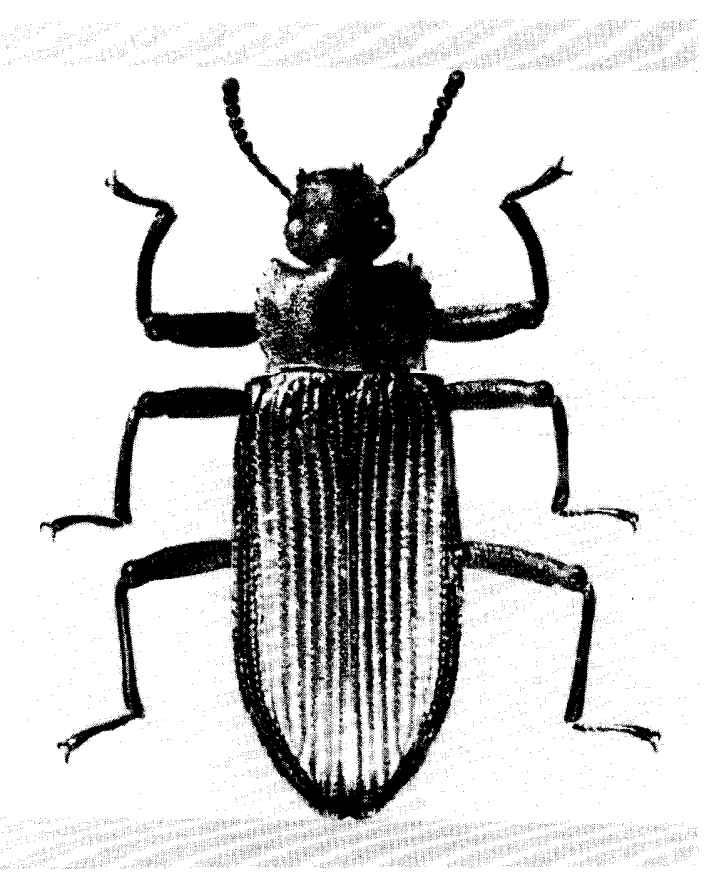

Catapiestus rugipennis M. T. Chajô, 1984.

This is a replacement of Fig. A, Catapiestus rugipennis sp. nov., in M. T. Chûjô's paper, Tenebrionidae of the Nansei Islands IX (Coleoptera), Esakia, (22) : 1-4, 1984. 